In: Barkhuizen, G. (2016). Reflections on language teacher identity research. London: Routledge.

\title{
Acknowledging the generational and affective aspects of language teacher identity
}

Lesley Harbon

University of Technology Sydney, Australia

\section{Looking back and looking forward}

From the moment my Indonesian teacher first stepped into my classroom I was in awe of her. I was growing up in a mono-lingual, mono-cultural English-speaking family in the northern part of Sydney, Australia, and until I met her, I never knew the magic of being able to make meaning in another language. She taught me intriguing new ways to look at the world. I had a good grasp on my English by junior high school, and now I was learning to know others' ways - at one level, the ways of the peoples of Indonesia, but on a second level, I reflect now, the ways of thinking, doing and being of the growing diversity of people in my district in the 1970s -- through other languages. With her guidance, I learned to ask questions about language per sé. I often look back to the time I spent in class with my first language teacher, to the generation of teachers before me, and I look forward too, to reflect on my own development as a language teacher and language teacher educator and the generations who have come after me. Looking back and looking forward, systematically, I believe, can be a productive exercise.

After graduating from high school, I became an Indonesian and German teacher in the 1980s and taught in secondary and primary programs. I moved into language teacher education in the 1990s. At two different points in those years I studied intensive short-term immersion programs in Japanese and Tetum. My vision for language teaching, first as a language teacher, and now as a language teacher educator, has become embedded in the notion of teaching 'culture-in-language', first introduced to me by my Indonesian teacher in the 1970s, and now underpinning my work with the preparation of new language teachers. My teacher had taught me about a different society, its people and their language and cultures. My language teacher - who was at the time a language teacher developing her own 'beginning teacher' identity - appears to have built her curriculum on the link between language and culture, and she shared this fascination to engage and motivate us in her classroom.

I recall that my teacher utilised dramatic techniques, music and song to teach Indonesian - my teacher sang beautifully in French, German and Indonesian. She placed a strong emphasis on communication skills, and we performed role-play dialogues in costume. Within the boundaries of the textbook I worked through the exercises and activities. But our teacher managed to expand the textbook material. She led us on wider pathways, and told us stories that clearly fascinated her about the other language and culture. In turn I was fascinated by these stories too. 'Living the language' was how my teacher offered her language program to us, allowing us to explore 'other' and 'self' on the journey together.

Varghese, Morgan, Johnston and Johnson (2005, p. 22) noted that "the teacher's whole identity...[is] at play in the classroom". If 'other' and 'self' combine to form 'identity', perhaps in the very act of teaching the language, my language teacher must logically have been exploring her identity. My teacher's own identity was affecting the way she taught us the language, and the 'culture-in- 
language' knowledge she explored made an impact on the landscape of "wonderments and puzzlements" of her language teacher education (Kleinsasser, 2013, p. 86).

These reflections on parts of my own career and identity development as I crossed the boundary between language teacher and language teacher educator, the notions I either gleaned or learned explicitly from the generation above me, and about the various languages I know now, are the building blocks that have made me so passionate about language teaching and learning today. This language teacher - me - became like her teacher, and then became a language teacher educator. Perhaps my students have become a little like me in turn. But I know that underpinning my identity as a language teacher and language teacher educator is the same human being, driven by the same beliefs, attitudes, emotions and passions. I realise that being able to trace my own and others' identity development through acknowledging the generational and affective aspects, is critical for me to advance the field with my continuing research. Below I track my thoughts about language teacher identity, positing my own definition from this 'generational' and 'affective' stance, and offering my ideas for how research on language teacher identity might develop if such questions are posed.

\section{Finding the language teacher inside me}

After considering that I taught two languages other than English in the first decade of my teaching career, and moved into language teacher education over the next 20 years, I view my somewhat eclectic set of research areas (I have published on bilingual education, intercultural language education, study-abroad education, and language teacher professional learning), to be based, first and foremost, on the importance of understanding language teacher identity. My work refers to (i) the notion that the professional decision-making of a language teacher is based on personal narrative (Harbon \& Moloney, 2013), (ii) the idea that the personal, affective aspect of language use in a study abroad situation impacts how language teachers dare to use the language they know (Harbon, 2007), and (iii) language teachers implementing bilingual programs according to their own narrative (Fielding \& Harbon, 2013), to name a few. In all my scholarly commentaries, I embark from an assumption that a language teacher's personal and professional identity development impacts every decision they make.

What other than language teacher identity can be considered to be at the heart of a language teacher's expertise, the essence of their professional work, the basis of "the sociocultural and sociopolitical landscape of the classroom" (Varghese et al., 2005) and the focus for researchers exploring problems in foreign and second language classrooms? Like the trends in thinking noted by Varghese et al. (2005, pp. 22-23), I too view a language teacher's identity, and a language teacher educator's identity, as dynamic not fixed, as related to context and settings, and embedded in the language and predominant educational/societal/political discourse. This holistic view of the language teacher (and in my view language teacher educator) understands language teachers'/language teacher educators' identities from a humanistic standpoint.

Korthagen (2004, p. 81) discussed the "humanistic-based approach (HBTE)" in the framing of a teacher's professional identity. It is the teachers (and I claim language teacher educators too) - the professionals, the experts, the decision-makers ultimately operationalising the micro-planning for their intended curriculum delivery plans - all the while considering the needs and characteristics of the learners - who bring the human element into language teaching and learning.

Reviewing these notions embedded in the current scholarly thinking about language teacher identity theorization, I can thus reflect on the considerable emphasis on 'identity' and related notions of personal narrative, reflection on self, in much of the language learning and teaching research I have so far published. 
The 'accomplished' language teacher and beyond

Language teacher organisations have variously consulted widely within their membership to define 'accomplished' teaching of language and cultures. One frame, designed and published in Australia, was the Professional standards for accomplished teaching of languages and cultures (hereafter Professional Standards) (Australian Federation of Modern Language Teachers' Associations (AFMLTA), 2005). Ten years ago I joined with language education scholars across Australia to help conceptualise and scope the nature of language teachers' work that became a basis for the Professional Standards (Liddicoat, Tognini, Fischmann, Kohler, Harbon, Scarino \& Dellit, 2005). We problematized and reflected on the meaning of 'accomplished' language and cultures teaching. The project resulted in a document that outlines seven dimensions of a language teacher's work.

Ten years later I consider now with hindsight, that in the Professional Standards document (AFMLTA, 2005), identity is under-emphasised. The Professional Standards suggest that because a language teacher is aware of "the role of language and culture in human interaction and identity" (AFMLTA, 2005, p. 4), they might therefore "use this knowledge to enhance their teaching". The nature of a language teacher's identity is, I believe, far more complex in its nature than that comment suggests. Identity development is likely to be embedded in language teachers' pedagogical decision making, and for language teachers surely, flavoured by the nuances and characteristics of the language itself.

A gap exists: the Professional Standards' frame and its cursory mention of the term 'identity' simply does not suffice to capture language teacher or language teacher educator identities. I contend that the generational (or even transgenerational element) - alluded to in Korthagen's (2004, p. 82) review of Kelchtermans and Vandenberghe's 1994 work relating to events and significant 'others' who influence us - should be part of the description of language teaching in the Professional Standards frame. To include the 'generational' aspect, the claim would be: I am a product of those who taught me, impacted by those who teach alongside me, and because I will teach others about the many reasons for learning at least one additional language, the cycle continues - inter- and trans-generationally.

In building my language teacher education curriculum for pre-service language teachers over the past almost 20 years I have introduced to pre-service teachers how language teaching methods have changed, and how the teachers who taught us were a product of how they constructed their programs, a product of the language taught/learned itself, a product of teaching material availability, and a product of current scholarly thinking about suitable pedagogy. There have been many changes across the generations particularly through the $20^{\text {th }}$ and now into the $21^{\text {st }}$ century. $\mathrm{A}$ language teacher's identity, as deconstructed in my own language teacher education curriculum program, starts from reflection across the generations as the embarkation point. As well, the preservice teachers meet the term 'identity' explicitly included in school language learning syllabus documentation which they then operationalise in their own classrooms with their learners.

\section{Acknowledging the generational aspect of language teacher identity}

The notion of "apprenticeship of observation" - we teach what we have observed teachers doing has been critiqued in recent years (Borg, 2004). Yet teachers need to learn (hone and refine) their craft of teaching within a context, understanding multiple contexts, acknowledging the specific language and its nuances, as well as their own personal and professional narratives. The 'affective' aspects of language teaching - the emotional aspects, the beliefs and attitudes at play in the background to any language teaching and learning - are evident because of the human element, and need to be acknowledged. In the preparation of new language teachers, it is common that solutions are found 'looking back' to what has worked in the past. Within the language teacher community 
there may even be a sense of awe and reverence to our own language teachers, as we saw them struggle to advocate for the teaching of foreign languages in contexts that were not always supportive, and sometimes even combative/confrontational. Current generations of language teachers may look back with a fond recollection of their own language teachers' struggles, to examine their strategies and their style, to examine what worked. We look back and we look forward, because to do so is a human trait. Thus investigating the 'affective' within the generational aspect of language teacher identity development - examining language teacher identity transgenerationally - makes a lot of sense.

The scholarly literature describes how the various generations are so different. In the second decade of the $21^{\text {st }}$ century we now track the learning styles and preferences of the generations who are present in our classrooms: the Baby Boomers, Generation X, Generation Y, Millennials, and their own priorities for learning (Wilson \& Gerber, 2008). Beginning language teachers, more accomplished language teachers and language teacher educators could all benefit from acknowledging the generational and affective aspects of language teaching. Further research could identify more explicit aspects of generational practices among language teachers: investigations into what the generations see as importantly explored in the language and culture aspects of 'self' and 'other', and even how each generation has taught the cultural nuances of the language itself. Moreover, a 'generational' consideration could develop the definition of 'accomplished' language teaching further. With a colleague (Harbon \& Moloney, 2013) I have been able to guide language teachers to investigate, reflect and write their personal and professional narratives. The process of guided writing itself aims to assist the writers themselves, then the readers, to acknowledge personal and professional life and work narratives in helping to create who they are now and why they teach the way they do. In a second layer, those narratives have become points of departure for both pre-service and in-service language teachers to start their own identity exploration.

Varghese et al. (2005, p. 21) warn that issues may arise should we rely on single theories of language teacher identity in isolation. The proposed step here is that adding a transgenerational stance, acknowledging the 'affective' factors, to the professional framing of language teacher identity and language teacher educator identity will bring a richness not explicitly factored in before. It should not represent the sole vantage point from which to view identity, but will enhance other theories that underpin the frame.

\section{Directions for future research}

There is much investigation still needed within the boundaries of what is considered to be language teacher identity research. This chapter has argued that the 'generational' and 'affective' aspects need to be considered, and qualitative research methods will arguably be the most suitable to undertake this investigation. Particularly important and informative will be studies such as transgenerational research which examines the inter- and trans-generational nature of language teacher development and language teacher educator development, and asks 'Do you believe you have assumed all or part of the identity of the teacher who taught you your additional language(s), and how does that embody itself?', and 'In what circumstances (in and outside the classroom) do you assume this identity and when do you depart from it?'

Narrative inquiry is one suitable methodology through which language teacher identity research has teased out the impact of one generation of language teachers on the next generation, exploring how teachers' bilingual/bicultural identities impact their pedagogies and allowing the 'affective' to emerge, and human emotive reactions, beliefs and attitudes to be acknowledged. Encouraging more than reflection, as just one example, a stimulated recall strategy on classroom practices could also allow language teachers to self-reflect, or work with peers/mentors to reflect and make meaning. 
My reflective practice, and my language teacher identity research has allowed me to look back on the past and forward to the future: in essence I cannot help but see things transgenerationally. Social media has allowed me to keep in touch with the language teacher who put my life on such a different path. Messages from former students still arrive in my Inbox, acknowledging my role as a teacher who set their lives on new paths. My teacher, myself and the many generations of students and language teachers who have come after us, find it easy to link with the generations who have come before and after us. What can enrich deeper understandings of language teacher identity are the stories emerging from the process of reflecting on the past and the planning for the future. The passion underpinning a language teacher's identity can be explored transgenerationally and affectively. Understanding the fine-detailed steps in that strategy, however, is something that will only emerge with further research.

\section{$\underline{\text { References }}$}

Australian Federation of Modern Language Teachers Associations. (2005). Professional standards for accomplished teaching of languages and cultures. Available online at:

<http://www.afmlta.asn.au/ebm3-doc/679729/Standards\%20for\%20teache.pdf>

Borg, M. (2004). The apprenticeship of observation. ELT Journal, 58 (3), 274-276.

Fielding, R. \& Harbon, L. (2013). Examining bilingual and bicultural identity in young students. Foreign Language Annals, 46 (4), 1 - 18. DOI: 10.1111/flan.12051

Harbon, L. (2007). Short term international experiences and teacher language awareness. International Education Journal, 8 (1), 229 - 243.

Harbon, L. \& Moloney, R. (2013). (Eds.). Language teachers' narratives of practice. Newcastle Upon Tyne, UK: Cambridge Scholars Publishing.

Kleinsasser, R.C. (2013). Language teachers: Research and studies in language(s) education, teaching and learning in Teaching and Teacher Education, 1985 - 2012. Teaching and Teacher Education, 29, $86-96$.

Korthagen, F.A.J. (2004). In search of the essence of a good teacher: towards a more holistic approach in teacher education. Teaching and Teacher Education, 20 (1), 77 - 97.

Liddicoat, A.J., Tognini, R., Fischmann, V., Harbon, L., Kohler, M., McLaughlin, M., Scarino, A. \& Dellit, J. (2005). Report of the development of standards for teachers of Indonesian project: Report to the Australian Government Department of Education, Science and Training. Canberra: Commonwealth of Australia.

Varghese, M., Morgan, B., Johnston, B., \& Johnson, K.A. (2005). Theorizing language teacher identity: three perspectives and beyond. Journal of Language, Identity \& Education, 4 (1), 21-44.

Wilson, M. \& Gerbert, L.E. (2008). How generational theory can improve teaching: Strategies for working with the Milennials. Currents in teaching and learning, 1 (1), $29-44$. 